\title{
Effect of date of sowing and rainfall on sustainability of yield and rainwater use efficiency in cereal crops under arid alfisols
}

\section{B.SAHADEVA REDDY ${ }^{1}$, B.RAVINDRANATHA REDDY, C.RADHA KUMARI, G.R.MARUTHI SANKAR, Y.ASHOKA REDDY and A.MALLISWARA REDDY}

\author{
Agricultural Research Station, Acharya N.G.Ranga Agricultural University, Anantapur -515001, Andhra Pradesh, \\ ${ }^{1}$ Agricultural College, Rajamahendravaram, East Godavari Dist-533103, Andhra Pradesh. \\ *Corresponding AuthorE-mail: sahadevardd@gmail.com
}

\begin{abstract}
An assessment of the effects of date of sowing and crop seasonal rainfall on the sustainability of yield and rainwater use efficiency (RWUE) of sorghum, pearl millet and foxtail millet sown on five dates at 15 days interval from first fortnight of June to first fortnight of August during 2009 to 2014 under arid Alfisols at Anantapur has been made in this paper. A suitable date of sowing has been identified for each crop based on the relationships sorghum equivalent yield with crop seasonal rainfall and crop growing period observed in the 6-year study. The yield was significantly influenced by the variation in the crop seasonal rainfall and crop growing period when sown on different dates of sowing. It was significantly higher when crops were sown with the onset of monsoon in the first fortnight of June, and decreased with the subsequent sowings. Among crops, sorghum attained maximum mean yield of $923 \mathrm{~kg} \mathrm{ha}^{-1}$ with RWUE of $2.73 \mathrm{~kg} \mathrm{ha}^{-1} \mathrm{~mm}^{-1}$; while pearl millet attained mean yield of $873 \mathrm{~kg} \mathrm{ha}^{-1}$ with RWUE of $2.95 \mathrm{~kg} \mathrm{ha}^{-}$ ${ }^{1} \mathrm{~mm}^{-1}$ and foxtail millet attained mean yield of $646 \mathrm{~kg} \mathrm{ha}^{-1}$ with RWUE of $1.64 \mathrm{~kg} \mathrm{ha}^{-1} \mathrm{~mm}^{-1}$ when sown during first fortnight of June. Based on the ranks assigned to the yield attained on different dates of sowing in different years, pearl millet was superior for sustaining maximum yield and RWUE compared to sorghum and foxtail millet under arid Alfisols at Anantapur.
\end{abstract}

Keywords: Crop seasonal rainfall, crop growing period, date of sowing, sorghum equivalent yield, rainwater use efficiency

About two thirds of the cultivated area in India is under rainfed farming which is often influenced by aberrant weather conditions. The rainfed regions make a major contribution to pulses, oilseeds and millet production. Due to erratic rainfall, rainfed farmers would often suffer by attaining low productivity and meager net returns from different crops. The erratic rainfall and its variability frequently affected the productivity of groundnut and other crops at Anantapur in the scarce rainfall zone of Andhra Pradesh. Among different factors, optimum date of sowing is an important determinant of crop yield when occurrence of rainfall is erratic. The sowing date of a crop would depend on the onset of monsoon, quantity and distribution of rainfall in any location. Some of the earlier studies indicated that delayed sowing of groundnut beyond July would significantly reduce the groundnut pod yield by about 70 per cent under dryland conditions (Reddy et al., 1984). In dryland agriculture, moisture is the most crucial input for crop production. The biotic and abiotic stresses such as prolonged and recurring dry spells during crop growth period would further add to the woes of a farmer. Based on crop and weather relationships, Ladda et al., (2010) observed significant effects of erratic rainfall and soil moisture on the productivity of cereal crops. Padmani et al.(2009) identified superior crop rotations for maximizing the productivity under erratic rainfall conditions in a semi-arid vertisol. An optimum date of sowing of a crop is essential for maximizing the yield under any soil and agro-climatic condition. About 61 per cent of rainfall is normally received during south-west monsoon period (June to September) which is important for rainfed crops under arid Alfisols at Anantapur. The deficiency and erratic distribution of rainfall would often lead to either delayed sowings or occurrence of stress at different stages of crops which would lead to crop failure. Though the longterm annual rainfall of the district is about $550 \mathrm{~mm}$, it received as low as $200 \mathrm{~mm}$ in below normal years and as high as $900 \mathrm{~mm}$ in above normal years. The monsoon would normally occur in the first week of June and get delayed even up to end of August. There is a high variation in the onset date which is typical feature of the district and is a major 
cause of uncertainty in the farming. The length of crop growing period was also vary depending on the onset, number of rainy days and withdrawal of monsoon (Maruthi Sankar et al., 2010). The erratic onset of monsoon and commencement of sowing rains would force the farmers to sow a crop under late monsoon season condition (Chandrika et al., 2008). In this study, field experiments were conducted with sorghum, pearl millet and foxtail millet on 5 dates of sowing during 2009 to 2014 with the objective of identifying an optimal date of sowing of crops for attaining sustainable yield and rainwater use efficiency under arid Alfisols.

\section{MATERIALS AND METHODS}

\section{Experimental details}

Field experiments were conducted for 6 years during kharif 2009 to 2014 at Anantapur under arid Alfisols located in the scarce rainfall zone of Andhra Pradesh at Latitude of $14^{\circ} 412 \mathrm{~N}$, Longitude of $77^{\circ} 402 \mathrm{E}$ and Altitude of 350 meters above mean sea level. The treatments consisted of 5 dates of sowing (DOS) viz.,

D1: first fortnight of June

D2: second fortnight of June

D3: first fortnight of July

D4: second fortnight of July

D5: first fortnight of August.

Sorghum, pearl millet and foxtail millet were sown with the receipt of rainfall on different dates of sowing. The experiments were conducted by adopting the date of sowing as main plots and crops as sub-plots in a split-plot design with 3 replications. Treatments were randomized only in the first year and were superimposed to same plots every year. The study was conducted in a red sandy loam soil which is near neutral in reaction ( $\mathrm{pH}$ of 6.9), low in organic carbon $(0.27 \%)$, soil $\mathrm{N}\left(63 \mathrm{~kg} \mathrm{ha}^{-1}\right)$, soil $\mathrm{K}\left(91 \mathrm{~kg} \mathrm{ha}^{-1}\right)$ and high in soil P (107 $\left.\mathrm{kg} \mathrm{ha}^{-1}\right)$. 'NTJ-4' variety of sorghum, 'Siri' variety of pearl millet and 'Srilakshmi' variety of foxtail millet were tested with seed rate@ 8,4 and $5 \mathrm{~kg} \mathrm{ha}^{-1}$. Sorghum and pearl millet had row x plant spacing of $45 \times 15 \mathrm{~cm}$, while foxtail millet had spacing of $30 \times 10 \mathrm{~cm}$. Recommended fertilizer dose of $60-40-30 \mathrm{~kg} \mathrm{ha}^{-1}$ of $\mathrm{N}, \mathrm{P}$ and $\mathrm{K}$ was applied to sorghum, compared to $60-30-20 \mathrm{~kg} \mathrm{ha}^{-1}$ to pearl millet and 40-30-0 $\mathrm{kg} \mathrm{ha}^{-1}$ to foxtail millet in each year.

During the experimental period (2009 to 2014) the onset of monsoon look place during June 1 to 16 and withdrawal occurred during October 16 to 29 , in different years with number of rainy days varying between 8 and 24 . The length of growing period of different crops were found to vary with dates of sowing as well as with season and year. In sorghum crop the seasonal rainfall over the year varied from $177 \mathrm{~mm}$ in 2014 to $601 \mathrm{~mm}$ in 2010 .

Similarly in pearl millet and fox millet there were large variation in rainfall received during the crop season in different years. The pooled analysis over dates of sowing and years suggested that the crop growing period ranged from 98 to 177 days for sorghum, 75 to 140 days for pearl millet and 80 to 124 days for foxtail millet with mean of 130 , 96 and 94 days respectively.

The differences in sorghum equivalent yield attained by crops on different DOS were compared based on least significant difference (LSD) criteria (Gomez and Gomez, 1984). The superiority of crops sown on different DOS was assessed and inferences were drawn about optimal DOS of crops under varying rainfall conditions. The rainwater use efficiency (RWUE, $\mathrm{kg} \mathrm{ha}^{-1} \mathrm{~mm}^{-1}$ ) was derived as ratio of sorghum equivalent yield $\left(\mathrm{kg} \mathrm{ha}^{-1}\right)$ attained by a crop and crop seasonal rainfall $(\mathrm{mm})$ of respective crop in each year (Rockstrom et al., 2003; Maruthi Sankar et al., 2012). Ranks were assigned to each crop for yield and RWUE and rank sums were derived for each sowing date. A superior crop with lowest rank sum was identified for each sowing date.

\section{RESULTS AND DISCUSSION}

\section{Effect of sowing dates on sorghum equivalent yield of crops}

The sorghum equivalent yield $\left(\mathrm{kg} \mathrm{ha}^{-1}\right)$ was determined by considering crop yield $\left(\mathrm{kg} \mathrm{ha}^{-1}\right)$ and prices of crops $\left(\mathrm{Rs} \mathrm{kg}^{-1}\right)$ for assessing the superiority of crops sown on different dates. The sorghum equivalent yield attained by crops sown on different sowing dates during 2009 to 2014 are given in Table 1. When sown in the first fortnight of June, the yield ranged from 601 to $1243 \mathrm{~kg} \mathrm{ha}^{-1}$, compared to 171 to $1758 \mathrm{~kg} \mathrm{ha}^{-1}$ under second fortnight of June, 305 to 2103 $\mathrm{kg} \mathrm{ha}^{-1}$ in the first fortnight of July, 214 to $1964 \mathrm{~kg} \mathrm{ha}^{-1}$ in the second fortnight of July and 14 to $470 \mathrm{~kg} \mathrm{ha}^{-1}$ in the first fortnight of August. The crop seasonal rainfall received during the crop growing period in the first fortnight of June gave maximum mean yield ( $\left.923 \mathrm{~kg} \mathrm{ha}^{-1}\right)$, followed by first fortnight of July ( $\left.901 \mathrm{~kg} \mathrm{ha}^{-1}\right)$, second fortnight of June (878 $\left.\mathrm{kg} \mathrm{ha}^{-1}\right)$, second fortnight of July $\left(565 \mathrm{~kg} \mathrm{ha}^{-1}\right)$ and first fortnight of August (256 kg ha-1) dates of sowing. When averages over dates of sowing, maximum mean yield of 1495 $\mathrm{kg} \mathrm{ha}^{-1}$ was attained in 2011 compared to minimum of 302 $\mathrm{kg} \mathrm{ha}^{-1}$ attained in 2013. 
Table 1: Effect of dates of sowing on sorghum equivalent yield and rainwater use efficiency

\begin{tabular}{|c|c|c|c|c|c|c|c|c|c|c|c|c|c|c|}
\hline \multirow[t]{2}{*}{ Crop } & \multicolumn{5}{|c|}{ Sorghum equivalent yield $\left(\mathrm{kg} \mathrm{ha}^{-1}\right)$} & \multirow[t]{2}{*}{ Mean } & \multirow[t]{2}{*}{$\mathrm{CV}$} & \multicolumn{5}{|c|}{ Rain water use efficiency $\left(\mathrm{kg} \mathrm{ha}^{-1} \mathrm{~mm}^{-1}\right)$} & \multirow[t]{2}{*}{ Mean } & \multirow[t]{2}{*}{$\mathrm{CV}$} \\
\hline & D1 & D2 & D3 & D4 & D5 & & & D1 & D2 & D3 & D4 & D5 & & \\
\hline \multicolumn{15}{|c|}{ Sorghum } \\
\hline 2009 & 861 & 1302 & 1590 & 248 & 14 & 803 & 84 & 2.78 & 4.57 & 7.57 & 1.23 & 0.12 & 3.26 & 90 \\
\hline 2010 & 656 & 322 & 348 & 254 & 222 & 360 & 48 & 1.02 & 0.53 & 0.51 & 0.46 & 0.43 & 0.59 & 42 \\
\hline 2011 & 1194 & 1758 & 2103 & 1964 & 453 & 1495 & 45 & 3.42 & 6.06 & 7.51 & 8.57 & 2.67 & 5.65 & 45 \\
\hline 2012 & 983 & 1012 & 561 & 473 & 470 & 700 & 39 & 2.73 & 3.30 & 2.37 & 2.77 & 3.22 & 2.88 & 13 \\
\hline 2013 & 601 & 171 & 305 & 214 & 219 & 302 & 58 & 1.59 & 0.47 & 0.99 & 0.90 & 4.39 & 1.67 & 94 \\
\hline 2014 & 1243 & 704 & 496 & 237 & 154 & 567 & 77 & 4.85 & 3.05 & 2.40 & 2.00 & 2.14 & 2.89 & 41 \\
\hline Mean & 923 & 878 & 901 & 565 & 256 & 704 & & 2.73 & 3.00 & 3.56 & 2.66 & 2.16 & 2.82 & \\
\hline $\mathrm{CV}$ & 29 & 69 & 84 & 123 & 69 & 61 & & 50 & 74 & 89 & 113 & 76 & 60 & \\
\hline \multicolumn{15}{|c|}{ Pearl millet } \\
\hline 2009 & 1032 & 952 & 761 & 590 & 373 & 742 & 36 & 4.41 & 4.64 & 3.64 & 2.94 & 3.25 & 3.77 & 19 \\
\hline 2010 & 1696 & 1687 & 909 & 761 & 601 & 1131 & 46 & 2.93 & 3.30 & 1.83 & 1.67 & 1.17 & 2.18 & 41 \\
\hline 2011 & 559 & 356 & 319 & 328 & 108 & 334 & 48 & 2.42 & 2.07 & 1.44 & 1.52 & 0.64 & 1.62 & 42 \\
\hline 2012 & 838 & 812 & 1052 & 678 & 413 & 759 & 31 & 2.78 & 2.94 & 4.74 & 4.38 & 2.83 & 3.53 & 27 \\
\hline 2013 & 219 & 912 & 553 & 308 & 111 & 421 & 76 & 0.63 & 2.75 & 1.80 & 1.30 & 2.22 & 1.74 & 47 \\
\hline 2014 & 892 & 664 & 624 & 841 & 336 & 671 & 33 & 4.53 & 3.82 & 3.14 & 7.13 & 4.67 & 4.66 & 32 \\
\hline Mean & 873 & 897 & 703 & 584 & 324 & 676 & & 2.95 & 3.25 & 2.76 & 3.15 & 2.46 & 2.92 & \\
\hline $\mathrm{CV}$ & 57 & 49 & 37 & 38 & 58 & 42 & & 49 & 27 & 47 & 72 & 59 & 43 & \\
\hline \multicolumn{15}{|c|}{ Foxtail millet } \\
\hline 2009 & 715 & 1029 & 94 & 428 & 17 & 457 & 93 & 3.06 & 5.02 & 0.45 & 2.13 & 0.15 & 2.16 & 92 \\
\hline 2010 & 715 & 798 & 704 & 439 & 237 & 579 & 40 & 1.32 & 1.59 & 1.41 & 0.75 & 0.53 & 1.12 & 41 \\
\hline 2011 & 1109 & 895 & 1257 & 462 & 339 & 812 & 49 & 4.80 & 5.20 & 5.61 & 2.14 & 2.00 & 3.95 & 44 \\
\hline 2012 & 319 & 470 & 755 & 425 & 351 & 464 & 37 & 1.06 & 1.70 & 3.40 & 2.64 & 2.40 & 2.24 & 40 \\
\hline 2013 & 314 & 154 & 37 & 151 & 120 & 155 & 65 & 0.90 & 0.44 & 0.12 & 0.65 & 2.39 & 0.90 & 98 \\
\hline 2014 & 704 & 359 & 633 & 331 & 177 & 441 & 50 & 3.89 & 2.11 & 3.18 & 3.01 & 2.45 & 2.93 & 23 \\
\hline Mean & 646 & 618 & 580 & 372 & 207 & 485 & & 2.51 & 2.68 & 2.36 & 1.88 & 1.65 & 2.22 & \\
\hline$C V$ & 46 & 55 & 79 & 32 & 63 & 44 & & 66 & 73 & 89 & 52 & 63 & 51 & \\
\hline
\end{tabular}

$\mathrm{CV}$ : Coefficient of variation (\%)

In pearl millet, sorghum equivalent yield $\left(\mathrm{kg} \mathrm{ha}^{-1}\right)$ ranged from 219 to $1696 \mathrm{~kg} \mathrm{ha}^{-1}$ when sown in the first fortnight of June, compared to 356 to $1687 \mathrm{~kg} \mathrm{ha}^{-1}$ in the second fortnight of June, 319 to $1052 \mathrm{~kg} \mathrm{ha}^{-1}$ in the first fortnight of July, 308 to $841 \mathrm{~kg} \mathrm{ha}^{-1}$ in the second fortnight of July and 108 to $601 \mathrm{~kg} \mathrm{ha}^{-1}$ in the first fortnight of August. The mean yield over years was maximum when sown in the second fortnight of June ( $\left.897 \mathrm{~kg} \mathrm{ha}^{-1}\right)$, followed by first fortnight of June ( $\left.873 \mathrm{~kg} \mathrm{ha}^{-1}\right)$, first fortnight of July $(703 \mathrm{~kg}$ $\left.\mathrm{ha}^{-1}\right)$, second fortnight of July $\left(584 \mathrm{~kg} \mathrm{ha}^{-1}\right)$ and first fortnight of August ( $\left.324 \mathrm{~kg} \mathrm{ha}^{-1}\right)$. Maximum mean yield of $1131 \mathrm{~kg} \mathrm{ha}$ ${ }^{1}$ was attained in 2010 compared to minimum of $334 \mathrm{~kg} \mathrm{ha}$ ${ }^{1}$ attained in 2011 when averaged over different dates of sowing.

In foxtail millet, sorghum equivalent yield $\left(\mathrm{kg} \mathrm{ha}^{-1}\right)$ ranged from 314 to $1109 \mathrm{~kg} \mathrm{ha}^{-1}$ when sown in the first fortnight of June, compared to 154 to $1029 \mathrm{~kg} \mathrm{ha}^{-1}$ in the second fortnight of June, 37 to $1257 \mathrm{~kg} \mathrm{ha}^{-1}$ in the first fortnight of July, 151 to $462 \mathrm{~kg} \mathrm{ha}^{-1}$ in the second fortnight of July and 17 to $351 \mathrm{~kg} \mathrm{ha}^{-1}$ in the first fortnight of August. 
The mean yield over years was maximum when sown in the first fortnight of June ( $\left.646 \mathrm{~kg} \mathrm{ha}^{-1}\right)$, followed by second fortnight of June ( $\left.618 \mathrm{~kg} \mathrm{ha}^{-1}\right)$, first fortnight of July $(580 \mathrm{~kg}$ $\left.\mathrm{ha}^{-1}\right)$, second fortnight of July $\left(372 \mathrm{~kg} \mathrm{ha}^{-1}\right)$ and first fortnight of August $\left(207 \mathrm{~kg} \mathrm{ha}^{-1}\right)$. Maximum mean yield of $812 \mathrm{~kg} \mathrm{ha}^{-}$ ${ }^{1}$ was attained in 2010 compared to minimum of $155 \mathrm{~kg} \mathrm{ha}-$ ${ }^{1}$ attained in 2013 when averaged over different dates of sowing.

The effect of crop seasonal rainfall on the sorghum equivalent yield attained by crops sown on different sowing dates are given in Table 2. There was a response of crops to early sowings compared to the delayed sowings in all years. The crop seasonal rainfall had a positive rate of change on all the 5 dates of sowing in pearl millet, while it was negative on all dates of sowing except $1^{\text {st }}$ fortnight of August in sorghum. In foxtail millet, it was positive when sown on $2^{\text {nd }}$ fortnight of July and $1^{\text {st }}$ fortnight of August, while it was negative on the remaining dates of sowing. The coefficient of determination ranged from 0.005 ( $1{ }^{\text {st }}$ fortnight of August) to 0.404 ( $1^{\text {st }}$ fortnight of June) in sorghum, while it ranged from 0.001 ( $2^{\text {nd }}$ fortnight of July) to 0.830 ( $2^{\text {nd }}$ fortnight of June) in pearl millet and 0.001 ( $1^{\text {st }}$ fortnight of July) to 0.094 ( $1^{\text {st }}$ fortnight of August) in foxtail millet.

Bacci et al., (1999) observed a significant effect of sowing dates and fertilizer N on millet yield in Mali. Chandrika et al., (2008) observed optimum utilization of above and below ground resources due to favorable weather parameters and maximum moisture availability in different phenophases which led to higher crop yield.

\section{Effect of dates of sowing on rainwater use efficiency}

The mean RWUE attained by crops on different dates of sowing in each year are given in Table 1. In sorghum, RWUE ranged from 1.02 to $4.85 \mathrm{~kg} \mathrm{ha}^{-1} \mathrm{~mm}^{-1}$ when sown in the first fortnight of June, compared to 0.47 to $6.06 \mathrm{~kg} \mathrm{ha}^{-}$ ${ }^{1} \mathrm{~mm}^{-1}$ in the second fortnight of June, 0.51 to $7.57 \mathrm{~kg} \mathrm{ha}^{-1}$ $\mathrm{mm}^{-1}$ in the first fortnight of July, 0.46 to $8.57 \mathrm{~kg} \mathrm{ha}^{-1} \mathrm{~mm}^{-1}$ in the second fortnight of July and 0.12 to $4.39 \mathrm{~kg} \mathrm{ha}^{-1}$ $\mathrm{mm}^{-1}$ in the first fortnight of August. The mean RWUE over years was maximum when sown in the first fortnight of July (3.56 kg ha-1 $\mathrm{mm}^{-1}$ ), followed by second fortnight of June ( $\left.3.00 \mathrm{~kg} \mathrm{ha}^{-1} \mathrm{~mm}^{-1}\right)$, first fortnight of June $\left(2.73 \mathrm{~kg} \mathrm{ha}^{-1} \mathrm{~mm}^{-}\right.$ $\left.{ }^{1}\right)$, second fortnight of July $\left(2.66 \mathrm{~kg} \mathrm{ha}^{-1} \mathrm{~mm}^{-1}\right)$ and first fortnight of August (2.16 kg ha' $\left.\mathrm{mm}^{-1}\right)$. Maximum mean RWUE of $5.65 \mathrm{~kg} \mathrm{ha}^{-1} \mathrm{~mm}^{-1}$ was attained in 2011 compared to minimum of $0.59 \mathrm{~kg} \mathrm{ha}^{-1} \mathrm{~mm}^{-1}$ attained in 2010 when averaged over different sowing dates.
In pearl millet, RWUE ranged from 0.63 to $4.53 \mathrm{~kg}$ $\mathrm{ha}^{-1} \mathrm{~mm}^{-1}$ when sown in the first fortnight of June, compared to 2.07 to $4.64 \mathrm{~kg} \mathrm{ha}^{-1} \mathrm{~mm}^{-1}$ in the second fortnight of June, 1.44 to $4.74 \mathrm{~kg} \mathrm{ha}^{-1} \mathrm{~mm}^{-1}$ in the first fortnight of July, 1.30 to $7.13 \mathrm{~kg} \mathrm{ha}^{-1} \mathrm{~mm}^{-1}$ in the second fortnight of July and 0.64 to $4.67 \mathrm{~kg} \mathrm{ha}^{-1} \mathrm{~mm}^{-1}$ in the first fortnight of August. The mean RWUE over years was maximum when sown in the second fortnight of June ( $\left.3.25 \mathrm{~kg} \mathrm{ha}^{-1} \mathrm{~mm}^{-1}\right)$, followed by second fortnight of July $\left(3.15 \mathrm{~kg} \mathrm{ha}^{-1} \mathrm{~mm}^{-1}\right)$, first fortnight of June $\left(2.95 \mathrm{~kg} \mathrm{ha}^{-1} \mathrm{~mm}^{-1}\right)$, first fortnight of July $\left(2.76 \mathrm{~kg} \mathrm{ha}^{-1} \mathrm{~mm}\right.$ $\left.{ }^{1}\right)$ and first fortnight of August $\left(2.46 \mathrm{~kg} \mathrm{ha}^{-1} \mathrm{~mm}^{-1}\right)$. Maximum mean RWUE of $4.66 \mathrm{~kg} \mathrm{ha}^{-1} \mathrm{~mm}^{-1}$ was attained in 2014 compared to minimum of $1.62 \mathrm{~kg} \mathrm{ha}^{-1} \mathrm{~mm}^{-1}$ attained in 2011 when averaged over different sowing dates.

In foxtail millet, RWUE ranged from 0.90 to $4.80 \mathrm{~kg}$ $\mathrm{ha}^{-1} \mathrm{~mm}^{-1}$ when sown in the first fortnight of June, compared to 0.44 to $5.20 \mathrm{~kg} \mathrm{ha}^{-1} \mathrm{~mm}^{-1}$ in the second fortnight of June, 0.12 to $5.61 \mathrm{~kg} \mathrm{ha}^{-1} \mathrm{~mm}^{-1}$ in the first fortnight of July, 0.65 to $3.01 \mathrm{~kg} \mathrm{ha}^{-1} \mathrm{~mm}^{-1}$ in the second fortnight of July and 0.15 to $2.45 \mathrm{~kg} \mathrm{ha}^{-1} \mathrm{~mm}^{-1}$ in the first fortnight of August. The mean RWUE was maximum when sown in the second fortnight of June $\left(2.68 \mathrm{~kg} \mathrm{ha}^{-1} \mathrm{~mm}^{-1}\right)$, followed by first fortnight of June $\left(2.51 \mathrm{~kg} \mathrm{ha}^{-1} \mathrm{~mm}^{-1}\right)$, first fortnight of July $\left(2.36 \mathrm{~kg} \mathrm{ha}^{-1}\right.$ $\left.\mathrm{mm}^{-1}\right)$, second fortnight of July $\left(1.88 \mathrm{~kg} \mathrm{ha}^{-1} \mathrm{~mm}^{-1}\right)$ and first fortnight of August $\left(1.65 \mathrm{~kg} \mathrm{ha}^{-1} \mathrm{~mm}^{-1}\right)$. Maximum mean RWUE of $3.95 \mathrm{~kg} \mathrm{ha}^{-1} \mathrm{~mm}^{-1}$ was attained in 2010 compared to minimum of $0.90 \mathrm{~kg} \mathrm{ha}^{-1} \mathrm{~mm}^{-1}$ attained in 2013 when averaged over different sowing dates.

The study indicated that with the amount of rainfall received during the crop growing period of sowings done in the first fortnight of June, sorghum and foxtail millet were superior, while pearl millet was superior when sown in the second fortnight of June. In sorghum, sowing in the first fortnight of June and first fortnight of July was superior for yield, while first and second fortnight of June were superior for RWUE. However, in pearl millet, sowing in the first fortnight of June was superior for yield, while second fortnight of June was superior for RWUE. Similarly, in foxtail millet, sowing in the first and second fortnight of June was superior for yield, while first fortnight of July was superior for RWUE over years.

\section{Relationship of sorghum equivalent yield with crop seasonal rainfall}

The relationships between crop seasonal rainfall and sorghum equivalent yield attained by sorghum, pearl millet and foxtail millet on different dates of sowing are described 


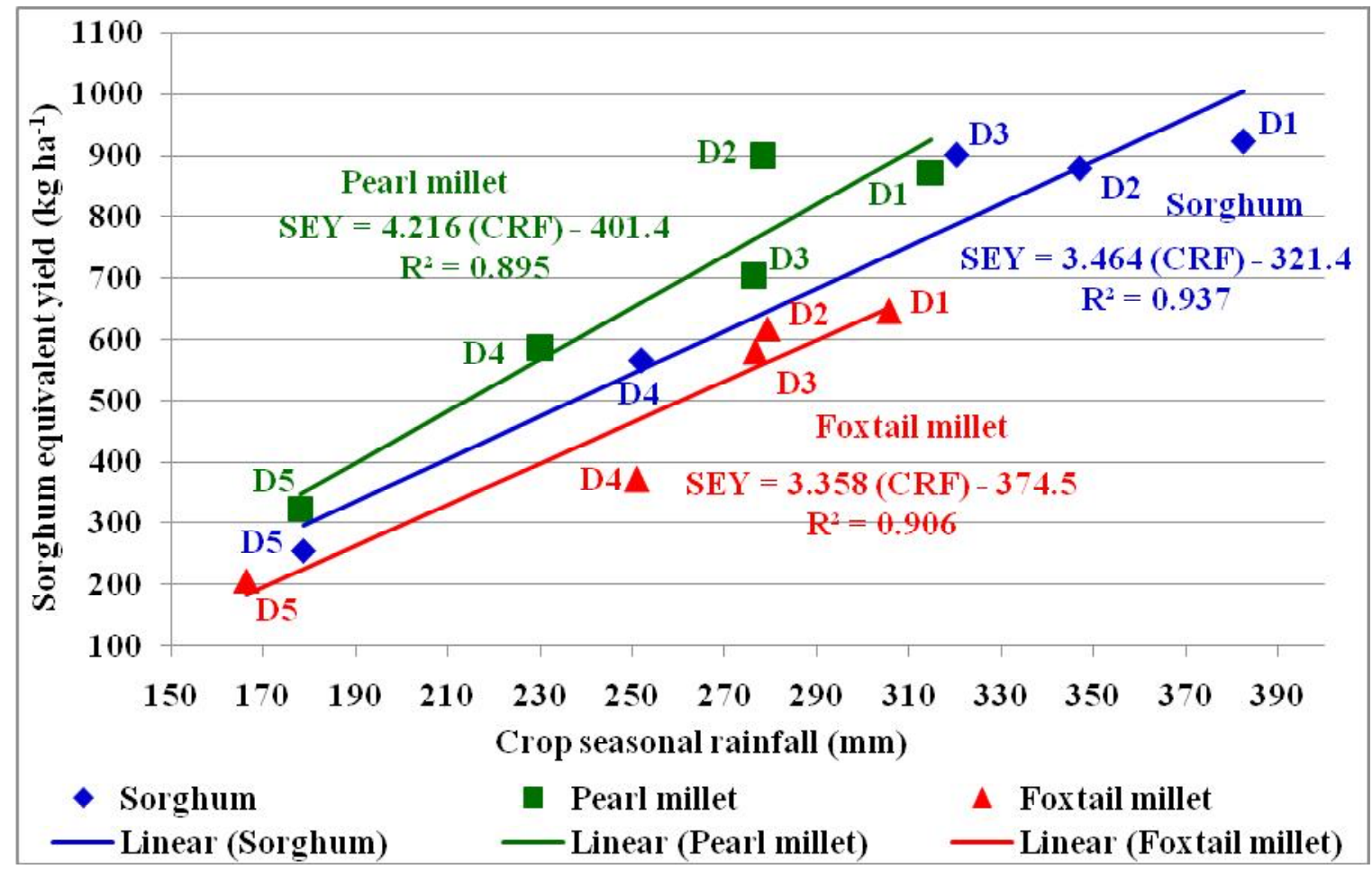

Fig 1. Superiority of crops based on their performance on different dates of sowing tested in different years

Table 2: Effect of crop seasonal rainfall (CRF) on yield attained by sorghum, pearl millet and foxtail millet during 2009 to 2014.

\begin{tabular}{llll}
\hline Crop & Date of sowing & Regression model & Coefficient of determination $\left(\mathrm{R}^{2}\right)$ \\
\hline Sorghum & First fortnight of June (D1) & $\mathrm{Y}=1407-1.266 \mathrm{CRF}$ & 0.404 \\
& Second fortnight of June (D2) & $\mathrm{Y}=1714-2.409 \mathrm{CRF}$ & 0.288 \\
& First fortnight of July (D3) & $\mathrm{Y}=1375-1.483 \mathrm{CRF}$ & 0.125 \\
& Second fortnight of July (D4) & $\mathrm{Y}=678-0.448 \mathrm{CRF}$ & 0.010 \\
& First fortnight of August (D5) & $\mathrm{Y}=243+0.072 \mathrm{CRF}$ & 0.005 \\
Pearl millet & First fortnight of June (D1) & $\mathrm{Y}=207+2.113 \mathrm{CRF}$ & 0.357 \\
& Second fortnight of June (D2) & $\mathrm{Y}=33+3.104 \mathrm{CRF}$ & 0.830 \\
& First fortnight of July (D3) & $\mathrm{Y}=516+0.676 \mathrm{CRF}$ & 0.088 \\
& Second fortnight of July (D4) & $\mathrm{Y}=566+0.078 \mathrm{CRF}$ & 0.001 \\
& First fortnight of August (D5) & $\mathrm{Y}=184+0.787 \mathrm{CRF}$ & 0.505 \\
& First fortnight of June (D1) & $\mathrm{Y}=803-0.515 \mathrm{CRF}$ & 0.049 \\
& Second fortnight of June (D2) & $\mathrm{Y}=700-0.294 \mathrm{CRF}$ & 0.012 \\
& First fortnight of July (D3) & $\mathrm{Y}=605-0.090 \mathrm{CRF}$ & 0.001 \\
& Second fortnight of July (D4) & $\mathrm{Y}=334+0.151 \mathrm{CRF}$ & 0.047 \\
& First fortnight of August (D5) & $\mathrm{Y}=161+0.275 \mathrm{CRF}$ & 0.094 \\
\hline
\end{tabular}

Fig 1. Based on the rate of change of sorghum equivalent yield for an unit change in the crop seasonal rainfall, rainfall had maximum effect on the yield attained by sorghum, followed by pearl millet and foxtail millet when sown on different dates of sowing in different years. However, the coefficient of determination $\left(\mathrm{R}^{2}\right)$ was maximum in pearl millet, followed by foxtail millet and sorghum based on the regression model of yield calibrated through the crop seasonal rainfall received when sown on different dates of sowing in each year during 2009 to 2014 . The model 
indicated the superiority of sowing in first fortnight of June for sorghum and foxtail millet, and second fortnight of June for pearl millet compared to other dates of sowing over years (Table 2).

The superior performance of crops when sown early with onset of monsoon was due to favourable weather in terms of rainfall distribution, sunshine hours and optimum temperature at reproductive and maturity stages of crops as well as higher RWUE. The late sown crops experienced either prolonged dry spells at flowering or maturity stage of crops or terminal drought which significantly reduced the yields. Soler et al., (2008) optimized planting dates for attaining maximum productivity of pearl millet in two different environments with variation in rainfall. Vittal et al., (2003) observed that timely sowing of crops resulted in harvesting good and moderate yields, whereas delayed sowing of crops resulted in low yields and inefficient use of resources. Sukadia and Dhoble (1990) and Padmani et al., (2009) observed superiority of groundnut with maximum yield at different sowing dates under semi-arid Vertisols. The ranks assigned to crops based on their performance on different dates of sowing indicated that pearl millet was efficient with significantly higher sorghum equivalent yield and RWUE with the amount of rainfall received in different years under arid Alfisols.

\section{CONCLUSIONS}

Based on field experiments conducted with sorghum, pearl millet and foxtail millet on 5 dates of sowing during 2009 to 2014 under arid Alfisols at Anantapur, a suitable date of sowing has been identified for attaining maximum rainwater use efficiency and sorghum equivalent yield in different years. The effects of crop seasonal rainfall and crop growing period on the performance of crops were assessed for sustaining yield and RWUE over years. The crop growing period decreased with sowings done from first fortnight of June to first fortnight of August. The yield attained by crops significantly decreased from the sowings done in the first fortnight of June to first fortnight of August in different years due to decreasing crop seasonal rainfall in different years. Due to erratic rainfall received in different years, the crops attained significantly lower yields. Even under lower crop seasonal rainfall and erratic distribution, pearl millet was superior when sown in the first fortnight of June and second fortnight of July compared to sorghum and foxtail millet. Based on the 6-year study, we recommend pearl millet for attaining sustainable sorghum equivalent yield and rainwater use efficiency under arid Alfisols.

\section{REFERENCES}

Bacci, L., Cantini, C., Pierini, F., Maracchi, G. and Reyniers, F.N. (1999). Effects of sowing date and nitrogen fertilization on growth, development and yield of a short day cultivar of millet in Mali. European J. Agron., 10: 9-21.

Chandrika, V., Parameswari, P. and Srinivas, G. (2008). Effect of sowing time and rainfall distribution on yield of rainfed groundnut in southern Agro-Climatic Zone of Andhra Pradesh. Legume Res., 31 (1): 54-56.

Gomez, K.A. and Gomez, A.A.(1984). Statistical procedures for agricultural research. Wileypublications Inc., New York.

Ladda, K.C., Maruthi Sankar, G.R., Sharma, S.K., Soddani, S.N. and Mishra, P.K. (2010). Modeling of effects of rainfall and soil moisture on productivity of maize and black gram in semi-arid Vertisols. J. Agrometeorol., 12 (1):2732.

Maruthi Sankar, G.R., Mishra, P.K., Srinivasa Rao, C.H., Padma Latha, Y., Sahadev Reddy, B., Babu, M.V.S., Ravindrnath Reddy, B., Veerabhadra Rao, K., Bhargavi, K., Ravindra Chary, G., Osman, M., Shalander Kumar., Vasundhara, S., Devasena, G.S. and Girija, A. (2010). Assessment of sustainability of groundnut yield using rainfall, soil moisture and soil fertility variables under arid alfisols. Indian J. Dryland Agric. Res. Dev., 25 (1): 39-46.

Maruthi Sankar, G.R., Subramanian, V., Sharma, K.L., Mishra, P.K., Jyothimani, S., Bhaskar, K., Jawahar, D., Rajeswari, M., Raghavan, T., Ravindra Chary, G., Renuka Devi, A., Gopinath, K.A., Venkateswarlu, B. and Kusuma Grace, J. (2012). Modeling of interactive effects of rainfall, evaporation, soil temperature and soil fertility for sustainable productivity of sorghum + cowpea \& cotton+black gram intercrops under rotation trials in a rainfed semi-arid Vertisol. Comm. Soil Sci. PlantAnal., 43 (5): 756-787.

Padmani, D.R., Maruthi Sankar, G.R.,Akbari, K.N., Gajera, M.S., Sutaria, G.S. and Khistaria, M.K. (2009). Sustainable rainfed crop sequence based on rainfall analysis under semi-arid Vertisol. J. Agrometeorol., 11 (1): 73-78.

Reddy, T.Y., Reddy, P.M., Reddy, T.B., Rami Reddy, S. and Sankara Reddi, G.H. (1984). Studies on suitable varieties of groundnut for normal and delayed sowings under rainfed conditions. Indian J. Agron., 29: 55-60.

Rockstrom, J., Barron, J. and Fox, P. (2003). Water productivity in rainfed agriculture: challenges and opportunities for 
smallholder farmers in drought-prone tropical agroecosystems. In Water Productivity in Agriculture: Limits \& Opportunities for Improvement, 145-162 (Eds W.Kijne, R.Barker and D.Molden). Wallingford: CAB International.

Soler, C.M.T., Maman, N., Zhang, X., Mason, S.C. and Hoogenboom, G. (2008). Determining optimum planting dates for pearl millet for two contrasting environments using a modeling approach. J. Agric. Sci., 146: 445459 .
Sukadia, N.M. and Dhoble, M.V.(1990). Studies on productivity and economics of different kharif crops as influenced by varying dates of sowing for aberrant weather situation under dryland conditions. Indian J. Agron., 35 (3): 229233.

Vittal, K.P.R., Maruthi Sankar, G.R., Singh, H.P., Balaguravaiah, D., Padmalatha, Y. and Yellamanda Reddy, T. (2003). Modeling sustainability of crop yield on rainfed groundnut based on rainfall and land degradation. Indian J. Dryland Agric. Res. Dev., 18: 7-13. 